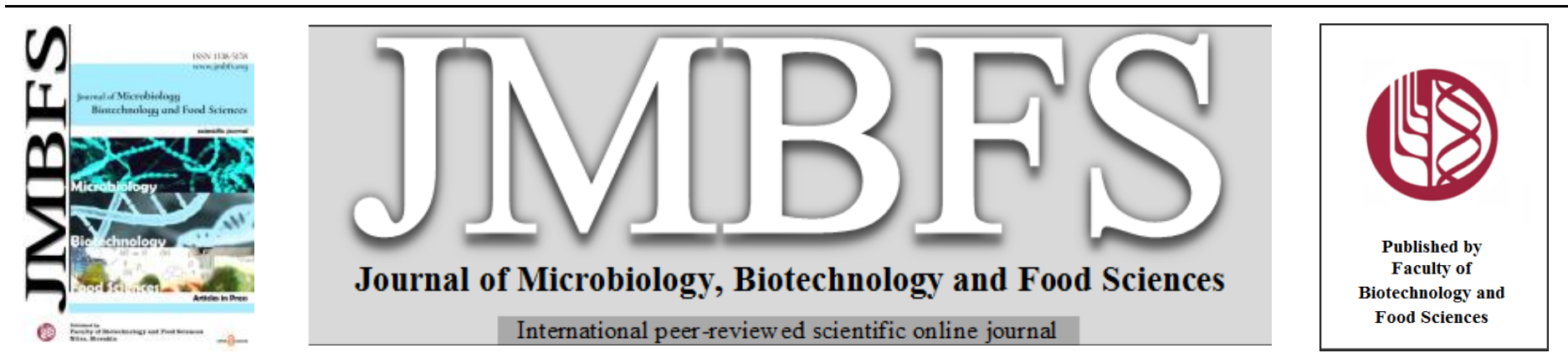

\title{
EFFECT OF PROCESSING AND STORAGE ON SAGE (SALVIA OFFICINALIS L.) HONEY QUALITY
}

\author{
Ivana Flanjak*, Daniela Kenjerić, Ivica Strelec, Blanka Bilić Rajs, Ljiljana Primorac
}

$\operatorname{Address(es):~prof.~Ivana~Flanjak~}$

Josip Juraj Strossmayer University of Osijek, Faculty of Food Technology Osijek, Franje Kuhača 18, HR-31000 Osijek, Croatia, +385 31224394

*Corresponding author: ivana.flanjak@ptfos.hr

https://doi.org/10.55251/jmbfs.3375

ARTICLE INFO

Received 2. 7. 2021

Revised 8. 12. 2021

Accepted 12. 1. 2022

Published 1. 6. 2022

Regular article

open $\mathcal{O}$ access

\section{ABSTRACT}

The aim of this study was to evaluate the effect of processing $\left(45^{\circ} \mathrm{C} / 48 \mathrm{~h}\right.$ and $\left.65^{\circ} \mathrm{C} / 6 \mathrm{~h}\right)$ and two years' storage on sage (Salvia officinalis L.) honey and to determine the period in which the compliance to the regulations is fulfilled and degradation of nutritive components are minimal. The results showed that processing at higher temperature for shorter period had a greater impact on enzyme activity decrease and increase of color than heating at lower temperature for longer time. Processing had no significant effect on HMF increase, while during storage HMF content increased above maximum prescribed value. Although processing and storage increased phenolic content and antioxidant capacity, at the same time, quality was significantly degraded regarding enzyme activity and HMF content. Therefore, it is recommended to store sage honey for less than two years and if processing is necessary to heat it at as low temperature as possible.

Keywords: sage honey, processing, storage, quality, shelf life

\section{INTRODUCTION}

Chemical composition and nutritional value of honey, as well as consumer's preferences, depends mainly on its botanical origin. Many honey components responsible for specific nutritive and biological properties are known to be unstable during storage and sensitive to heat (Escriche et al., 2009; Fauzi et al., 2014; Karabagias et al., 2017; Önür et al., 2018). Before placing to the market, honey is often processed with the aim of viscosity decrease, delaying and/or preventing crystallization and fermentation control in order to facilitate manipulation and ensure storage stability (Subramanian et al., 2007). Although, several innovative techniques have been used for honey processing (Kowalski, 2013; Wilczyńska, 2014; Fauzi et al., 2014; Önür et al., 2018), the beekeepers and traders usually still heat honey to achieve desirable processing effect. It is known that heating causes honey quality degradation, like enzyme activity decrease, increase of 5(hydroxymethyl)furan-2-carbaldehyde (HMF) content, darkening of honey and formation of Maillard reaction products (MRPs). The intensity of changes is strongly dependent on applied temperature and heating duration (Turhan et al. 2008; Escriche et al., 2014; Karabagias et al., 2017; Radtke and LichtenbergKraag, 2018; Merve Turkut et al., 2018). Heat treatments lasting 1-2 days at 40$50{ }^{\circ} \mathrm{C}$ will not cause significant changes, while the application of temperatures of 50-60 ${ }^{\circ} \mathrm{C}$ increases the intensity of changes and impairs the quality of honey. Application of pasteurization temperatures $\left(63-68{ }^{\circ} \mathrm{C} / 30-35\right.$ minutes or 77 ${ }^{\circ} \mathrm{C} /$ several seconds) will completely inactivate the yeasts responsible for fermentation and delay crystallization, but at these temperatures a decrease in enzyme activity is visible (Dimiņš et al., 2006; Merve Turkut et al., 2018; Radtke and Lichtenberg-Kraag, 2018). It is recommended to heat the honey at the lowest possible temperatures and for as short a time as possible in order to achieve the desired processing effect.

Honey is packed in glass or plastic containers that are intended for consummation over a longer period and therefore it is important to maintain quality as much as possible during storage. Critical factors that affect honey quality during storage are relative humidity, temperature and the presence of light in storage rooms. Improper storage conditions can lead to the changes of sensory characteristics (mainly color and aroma), the loss of biologically active components, like enzymes and other antimicrobial components, and honey fermentation (Brudzynski and Kim, 2011) Furthermore, storage affects carbohydrate composition, increase of honey acidity and HMF formation (Monggudal et al., 2018; Radtke and Lichtenberg-Kraag, 2018). Due to the natural variability of honey components and the number of factors that affect its' quality, it is very difficult to estimate the processing and storage conditions that minimize degradation of honey. Namely, available studies showed that the intensity of changes during processing and storage is strongly dependent on honey botanical origin (Wang et al., 2004; Dimiṇš et al., 2006; Brudzyinski and Miotto, 2011a; Kowalski, 2013).

Sage (Salvia officinalis L.) honey is one of the most important Croatian unifloral honey type and one of the most appreciated among consumers. Characterization of this specific honey type from different aspects is documented in our previous papers (Kenjerić et al., 2006; Kenjerić et al., 2008; Čačić Kenjerić et al., 2009; Primorac et al., 2011; Flanjak et al., 2016a; Flanjak et al., 2016b; Strelec et al., 2018).

Having in mind that botanical origin and post extraction manipulation have a great impact on honey quality alterations, the aim of this work was to estimate dynamic of changes after different processing treatments and two years' storage on sage honey. The results of this study can be useful for estimation of "best before" date for sage honey in which the compliance to the regulations is fulfilled and degradation of nutritive components are minimal.

\section{MATERIAL AND METHODS}

Honey samples

Five sage ( $S$. officinalis $\mathrm{L}$.) honey samples ( $10 \mathrm{~kg}$ of each sample) were purchased from the beekeepers from different parts of Adriatic region of Croatia. Each sample was first homogenized in a large container and divided into 3 series (unprocessed, UP; processed, P1 and P2). The glass containers were filled to the top and sealed, and were not opened until analysis. Unprocessed samples (UP) were analyzed without any processing/heating while other two series of samples (P1 and P2) were heated under different temperature-time conditions. P1 processing treatment included heating of samples at $45^{\circ} \mathrm{C}$ for 48 hours while the $\mathrm{P} 2$ processing treatment was performed by heating samples at $65{ }^{\circ} \mathrm{C}$ for 6 hours. Thermal processing was performed in the temperature controlled heating chamber with forced convection (BINDER FED 53, USA). After cooling at the room temperature, following physicochemical parameters were determined: HMF content, activities of diastase, invertase, glucose oxidase (GOX) and acid phosphatase (AP), phenolic content, antioxidant capacity with DPPH and FRAP assays, color determinations (color intensity and color grading) and fluorescence measurement.

Both unprocessed (UP) and processed samples (P1 and P2) were stored at the room temperature in the dark place. Determination of HMF content, activity of diastase, invertase, GOX and AP, phenolic content, antioxidant capacity (DPPH and FRAP assays), color determinations and fluorescence measurement were conducted after 12 and 24 months of storage, respectively. 


\section{Methods}

Melissopalynological analysis of collected honey samples was performed as according to the harmonized methods of melissopalynology (von der Ohe et al. 2004) while preparation of slides without acetolysis for microscopical examination was done according to the method of Louveaux $\boldsymbol{e t}$ al. (1978). Identification and counting of pollen grains in prepared slides was performed under a microscope at 400-1000x magnification. Pollen grains identification was made by reference to the literature data (Von der Ohe and Von der Ohe, 2003; Kenjerić et al., 2006) Qualitative melissopalynological analysis, identification and counting of pollen grains of the predominant plant species, was performed on all samples in order to confirm uniflorality of colleted samples. Final confirmation of uniflorality was done based on the results of mellisopalinological analysis (Ministry of Agriculture, Fisheries and Rural Development, 2009), sensory characteristics (Piana et al., 2004; Kenjerić et al., 2006) and selected physicochemica parameters that are usually correlated to honey botanical origin.

Basic physicochemical parameters determination was conducted according to the international methods for honey analyses (International Honey Commission, 2009; AOAC International, 2002). Moisture content was determined using refractometric method, electrical conductivity was measured in a solution of $20 \mathrm{~g}$ honey dry matter in a low conductivity distilled water, HMF content was determined using method after White, diastase and invertase activities using spectrophotometric methods after Shade and Siegenthaler, respectively. Specific rotation was determined by means of polarimeter while carbohydrate content was determined by chromatographic (HPLC) method (International Honey Commission, 2009). Initial $\mathrm{pH}$ of honey, and afterwards free acidity, lactones and total acidity were determined by titrimetric method according to the AOAC Official Methods (AOAC International, 2002).

Glucose oxidase (GOX) activity was determined according to the Schepartz \& Subers (1964). The quantification was performed using $\mathrm{H}_{2} \mathrm{O}_{2}$ as standard (Fluka Germany) with peroxidase and $o$-dianisidine and the results were expressed as $\mu \mathrm{g}$ $\mathrm{H}_{2} \mathrm{O}_{2} / \mathrm{h}$ g honey.

Acid phosphatase (AP) activity determination was performed as described Bergmeyer et al. (1974). The results of acid phosphatase activity were expressed as $\mathrm{mg} \mathrm{P} / 100 \mathrm{~g}$ honey/24 $\mathrm{h}$.

Phenolic content was determined by modified Folin-Ciocalteu method described by Beretta et al. (2005). The quantification was performed using gallic acid (Sigma, USA) as standard and the results were expressed as mg gallic acid $/ \mathrm{kg}$ honey.

Antioxidant capacity was determined using two spectrophotometric assays. The antiradical/antioxidant capacity by DPPH assay was performed as described Brand-Williams et al. (1995) and Berreta et al. (2005). The antiradical capacity of honey samples was expressed as $\mathrm{IC}_{50}$, a honey concentration $(\mathrm{mg} / \mathrm{mL})$ that causes a decrease of the initial DPPH radical concentration by $50 \%$. For the determination of total antioxidant capacity, the assay reported by Benzie and Strain (1996) was used. Aqueous standard solutions of $\mathrm{FeSO}_{4} \cdot 7 \mathrm{H}_{2} \mathrm{O}(\mathrm{Kemika}$ Croatia) were used for calibration curve and the results were expressed as the FRAP value ( $\mu \mathrm{M} \mathrm{Fe(II)} \mathrm{of} \mathrm{the} 10 \%$ honey solution).

The color of honey was evaluated using two methods. Color grading was determined by Lovibond Honey ColorPod that measures transmittance at 430 and $530 \mathrm{~nm}$ of homogeneous, liquid honey, as compared with the transmittance of pure glycerin. The transmitted light was related to the Pfund color scale and the results were expressed as $\mathrm{mm}$ of Pfund (AOAC International, 2002). Spectrophotometric honey color determination (net absorbance), defined as the difference between absorbance measurements at 450 and $720 \mathrm{~nm}$ was performed as described Beretta et al. (2005) and the results were expressed mAU.

Fluorescence measurement was performed according to the procedure described in our previous study (Strelec $\boldsymbol{e t}$ al., 2018). Three dimensional fluorescence spectra recordings were performed by scanning with excitation wavelengths from 260 to $400 \mathrm{~nm}$, and emission wavelengths from 300 to $600 \mathrm{~nm}$ while fluorescence intensity was measured at 280/350 nm (excitation/emission), and at 360/460 nm.

\section{Statistical analysis}

Average values, standard deviations and range for each parameter were given. In order to evaluate statistical difference between processing conditions and storage factorial analysis of variance (ANOVA) and post-hoc Tukey HSD test were performed using software STATISTICA ${ }^{\circledR} 13.3$ (Dell Inc., Round Rock, TX, USA). p-values $<0.05$ were considered significant

\section{RESULTS AND DISCUSSION}

\section{Botanical origin confirmation}

With the aim of botanical origin confirmation of collected samples, melissopalynological analysis was performed. The results of melissopalynological analysis were presented in table 1 . All analyzed samples fulfilled the requirement of minimum $15 \%$ of $S$. officinalis L. pollen share in insoluble honey sediment, or
$10 \%$ together with characteristic sensory attributes for sage honey (Ministry of Agriculture, Fisheries and Rural Development, 2009). Sensory characteristics (colour, odour, and aroma) of collected samples correspond to those described in our previous paper where sage honey characteristics are described (Kenjerić $\boldsymbol{e t}$ al. 2006). Furthermore, determined physicochemical quality parameters (table 1) were in compliance to national (Ministry of Agriculture, 2015) and international regulations (Codex Alimentarius Commission, 2001; Council of the European Union, 2002). Based on the results of melissopalynological analysis physicochemical parameters and sensory analysis, samples can be classified as unifloral sage (S. officinalis L.) honey.

Table 1 Average values, standard deviations (SD) and range for melissopalynological analysis and physicochemical parameters of analyzed sage (S. officinalis L.) honey samples

\begin{tabular}{lcccc}
\hline Parameter & Average & SD & Minimum & Maximum \\
\hline $\begin{array}{l}\text { S. officinalis L. pollen } \\
\text { share }(\%)\end{array}$ & 19 & 6 & 11 & 26 \\
Moisture $(\%)$ & 16.8 & 0.8 & 15.8 & 17.8 \\
Electrical conductivity & 0.299 & 0.06 & 0.221 & 0.386 \\
$(\mathrm{mS} / \mathrm{cm})$ & 4.03 & 0.08 & 3.97 & 4.16 \\
$\mathrm{pH}$ & 20.7 & 3.3 & 15.4 & 23.4 \\
Free acidity $(\mathrm{mmol} / \mathrm{kg})$ & 6.5 & 1.5 & 4.6 & 8.0 \\
Lactones $(\mathrm{mmol} / \mathrm{kg})$ & 27.2 & 4.7 & 20.0 & 31.2 \\
Total acidity $(\mathrm{mmol} / \mathrm{kg})$ & -16.8 & 1.4 & -18.5 & -14.9 \\
Specific rotation $(\alpha)_{D}^{20}$ & 1.26 & 0.05 & 1.20 & 1.32 \\
F/G & 72.0 & 2.4 & 69.9 & 75.9 \\
F+G $(\mathrm{g} / 100 \mathrm{~g})$ & & & & \\
\hline
\end{tabular}

\section{Effect of processing and storage on enzyme activities and HMF content}

Honey is a food product that is often processed to ease further manipulation. Processing usually refers to heating honey at different temperatures for different time. The beekeepers and traders often heat honey at temperatures from 40 to 45 ${ }^{\circ} \mathrm{C}$ for few days in hot air chambers to recrystallize honey since crystallized honey is less attractive to consumers than liquid one but also to facilitate packaging (Escriche et al., 2009, Karabagias et al., 2017). Temperatures higher than $45^{\circ} \mathrm{C}$ are necessary for inactivation of yeast responsible for fermentation of honey in inadequate conditions. Temperatures between 63 to $68^{\circ} \mathrm{C}$ for few hours are used for honey pasteurization (Babacan et al., 2002; Subramanian et al., 2007; Merve Turkut et al., 2018). Processing conditions applied in this study (P1 and P2) were selected with the aim of evaluation of decrystallization and pasteurization temperatures on sage honey quality. Honey is packed in glass or plastic containers, stored usually at room temperature and not consumed at once but for some time. "Best before" date for honey is stated two years but honey quality alters during storage (Brudzynski and Kim, 2011; Monggudal et al., 2018; Radtke and Lichtenberg-Kraag, 2018). Additionally, the aim of this study was to evaluate the intensity of changes in unprocessed and processed sage honey for two years, and to investigate possible synergistic effect of processing and storage on sage honey quality.

Enzyme activity and HMF content are considered as indicators of honey processing and storage conditions. Average HMF content of collected samples was $2.0 \pm 0.04$ $\mathrm{mg} / \mathrm{kg}$ (table 2, figure 1) while average diastase activity, expressed as diastase number (DN), was $17.5 \pm 4.6$ (table 2) which purports the fact that samples were fresh and unprocessed. Both processing treatments (P1 and $\mathrm{P} 2)$ caused decrease of enzyme activity.

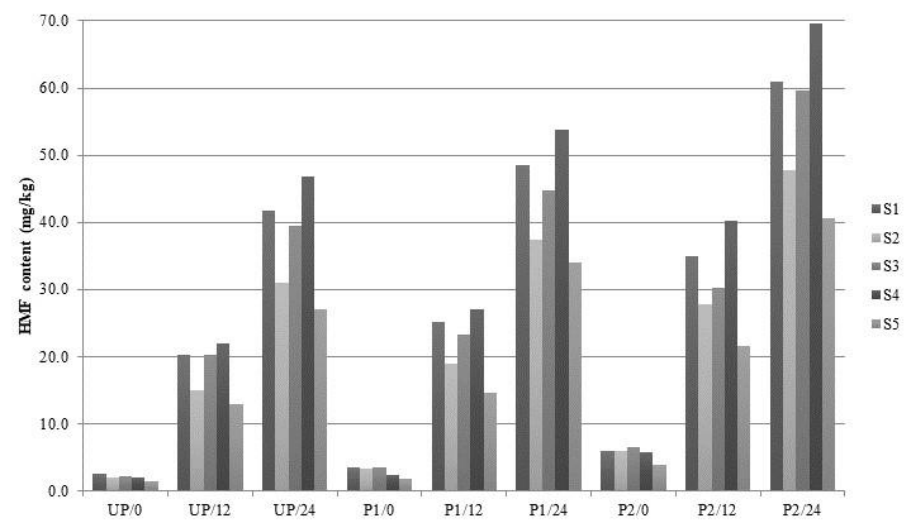

Figure $1 \mathrm{HMF}$ content of analyzed sage honey samples (S1-S5) after processing and storage (UP-unprocessed, $\mathrm{P} 1-45^{\circ} \mathrm{C} / 48 \mathrm{~h}, \mathrm{P} 2-65^{\circ} \mathrm{C} / 6 \mathrm{~h} ; 0,12$ and 24 represent months of storage) 
Table 2 Effect of different processing conditions (P1 and P2) and storage on selected physicochemical parameters (average \pm SD)

\begin{tabular}{|c|c|c|c|c|}
\hline Parameter & Storage period & Unprocessed (UP) & After $\mathrm{P} 1\left(45^{\circ} \mathrm{C} / 48 \mathrm{~h}\right)$ & After P2 $\left(65^{\circ} \mathrm{C} / 6 \mathrm{~h}\right)$ \\
\hline \multirow{3}{*}{ Diastase activity (DN) } & 0 & $17.5 \pm 4.6^{\mathrm{a}}$ & $16.0 \pm 4.3^{\mathrm{a}, \mathrm{b}}$ & $12.5 \pm 3.3^{\mathrm{a}, \mathrm{b}}$ \\
\hline & 12 months & $13.4 \pm 3.4^{\mathrm{a}, \mathrm{b}}$ & $12.4 \pm 3.2^{\mathrm{a}, \mathrm{b}}$ & $10.7 \pm 2.7^{\mathrm{a}, \mathrm{b}}$ \\
\hline & 24 months & $11.9 \pm 3.0^{\mathrm{a}, \mathrm{b}}$ & $11.5 \pm 2.9^{\mathrm{a}, \mathrm{b}}$ & $9.8 \pm 2.5^{\mathrm{b}}$ \\
\hline \multirow{3}{*}{ Invertase activity (U/kg) } & 0 & $92.5 \pm 27.8^{\mathrm{a}, \mathrm{b}}$ & $66.4 \pm 25.6^{\mathrm{a}, \mathrm{b}, \mathrm{c}, \mathrm{d}, \mathrm{e}}$ & $7.0 \pm 5.6^{\mathrm{d}, \mathrm{e}, \mathrm{f}, \mathrm{g}}$ \\
\hline & 12 months & $58.3 \pm 20.2^{\mathrm{a}, \mathrm{b}, \mathrm{c}, \mathrm{d}, \mathrm{e}}$ & $44.9 \pm 20.6^{\mathrm{b}, \mathrm{c}, \mathrm{d}, \mathrm{e}, \mathrm{f}}$ & $3.9 \pm 2.7^{\mathrm{e}, \mathrm{f}, \mathrm{g}}$ \\
\hline & 24 months & $48.4 \pm 19.6^{\mathrm{b}, \mathrm{c}, \mathrm{d}, \mathrm{e}}$ & $36.8 \pm 17.5^{\text {b,c,de,f,g }}$ & $3.7 \pm 3.2^{\mathrm{e}, \mathrm{f}, \mathrm{g}}$ \\
\hline \multirow{3}{*}{ GOX activity $\left(\mu \mathrm{g} \mathrm{H}_{2} \mathrm{O}_{2} / \mathrm{h} \mathrm{g}\right)$} & 0 & $223.6 \pm 104.9^{\mathrm{a}}$ & $211.9 \pm 94.0^{\mathrm{a}}$ & $34.9 \pm 46.3^{\mathrm{b}}$ \\
\hline & 12 months & $223.4 \pm 90.5^{\mathrm{a}}$ & $206.7 \pm 82.7^{\mathrm{a}}$ & $17.3 \pm 20.1^{\mathrm{b}}$ \\
\hline & 24 months & $220.0 \pm 85.5^{\mathrm{a}}$ & $212.0 \pm 86.4^{\mathrm{a}}$ & $27.6 \pm 30.0^{\mathrm{b}}$ \\
\hline \multirow{3}{*}{$\begin{array}{l}\text { AP activity } \\
(\mathrm{mg} \mathrm{P} / 100 \mathrm{~g} \text { honey/24 h) }\end{array}$} & 0 & $47.3 \pm 18.4^{\mathrm{a}}$ & $37.2 \pm 11.6^{\mathrm{a}}$ & $29.6 \pm 6.7^{\mathrm{a}}$ \\
\hline & 12 months & $47.0 \pm 18.1^{\mathrm{a}}$ & $38.6 \pm 10.5^{\mathrm{a}}$ & $29.1 \pm 5.8^{\mathrm{a}}$ \\
\hline & 24 months & $33.4 \pm 14.0^{\mathrm{a}}$ & $34.3 \pm 14.9^{\mathrm{a}}$ & $26.4 \pm 15.0^{\mathrm{a}}$ \\
\hline \multirow{3}{*}{ HMF content (mg/kg) } & 0 & $2.0 \pm 0.4^{\mathrm{a}, \mathrm{f}}$ & $2.9 \pm 0.8^{\mathrm{a}, \mathrm{f}}$ & $5.6 \pm 1.0^{\mathrm{a}, \mathrm{b}, \mathrm{f}}$ \\
\hline & 12 months & $18.0 \pm 4.0^{\mathrm{b}, \mathrm{d}, \mathrm{f}}$ & $21.8 \pm 5.0^{\mathrm{b}, \mathrm{d}, \mathrm{g}}$ & $30.9 \pm 7.1^{\mathrm{b}, \mathrm{c}, \mathrm{d}, \mathrm{e}, \mathrm{g}}$ \\
\hline & 24 months & $37.2 \pm 8.1^{\mathrm{c}, \mathrm{e}}$ & $43.7 \pm 8.1^{\mathrm{c}, \mathrm{e}, \mathrm{g}, \mathrm{h}}$ & $55.7 \pm 11.5^{\mathrm{e}, \mathrm{h}}$ \\
\hline \multirow{3}{*}{ Net absorbance (mAU) } & 0 & $228 \pm 45^{\mathrm{a}, \mathrm{b}}$ & $248 \pm 50^{\mathrm{a}, \mathrm{b}, \mathrm{d}}$ & $275 \pm 57^{\mathrm{a}, \mathrm{b}, \mathrm{d}}$ \\
\hline & 12 months & $320 \pm 52^{\mathrm{a}, \mathrm{b}, \mathrm{c}, \mathrm{d}}$ & $340 \pm 54^{\mathrm{a}, \mathrm{b}, \mathrm{c}, \mathrm{d}, \mathrm{e}}$ & $407 \pm 55^{\mathrm{b}, \mathrm{c}, \mathrm{d}, \mathrm{e}}$ \\
\hline & 24 months & $406 \pm 52^{\mathrm{b}, \mathrm{c}, \mathrm{d}, \mathrm{e}}$ & $441 \pm 62^{\mathrm{c}, \mathrm{d}, \mathrm{e}}$ & $528 \pm 69^{\mathrm{e}, \mathrm{f}}$ \\
\hline \multirow{3}{*}{ Color (mm Pfund) } & 0 & $49 \pm 6^{\mathrm{a}, \mathrm{d}, \mathrm{e}}$ & $52 \pm 6^{\mathrm{a}, \mathrm{b}, \mathrm{d}, \mathrm{e}}$ & $56 \pm 5^{\mathrm{a}, \mathrm{b}, \mathrm{c}, \mathrm{d}, \mathrm{e}}$ \\
\hline & 12 months & $59 \pm 2^{\mathrm{b}, \mathrm{c}, \mathrm{d}, \mathrm{e}, \mathrm{f}}$ & $60 \pm 2^{\mathrm{b}, \mathrm{c}, \mathrm{e}, \mathrm{f}}$ & $66 \pm 3^{\mathrm{b}, \mathrm{c}, \mathrm{f}}$ \\
\hline & 24 months & $62 \pm 1^{\mathrm{b}, \mathrm{c}, \mathrm{e}, \mathrm{f}}$ & $63 \pm 2^{\text {b,c,e,f }}$ & $67 \pm 3^{\mathrm{b}, \mathrm{c}, \mathrm{f}}$ \\
\hline \multirow{3}{*}{$\begin{array}{l}\text { Phenolic content } \\
\text { (mg gallic acid/kg honey) }\end{array}$} & 0 & $90.9 \pm 16.4^{\mathrm{a}, \mathrm{b}}$ & $102.7 \pm 18.6^{\mathrm{a}, \mathrm{b}, \mathrm{c}}$ & $112.5 \pm 21.6^{\mathrm{a}, \mathrm{b}, \mathrm{c}, \mathrm{d}}$ \\
\hline & 12 months & $122.7 \pm 21.4^{\mathrm{a}, \mathrm{b}, \mathrm{c}, \mathrm{d}}$ & $128.2 \pm 21.3^{\mathrm{a}, \mathrm{b}, \mathrm{c}, \mathrm{d}}$ & $142.7 \pm 21.8^{\mathrm{b}, \mathrm{c}, \mathrm{d}}$ \\
\hline & 24 months & $132.5 \pm 20.5^{\mathrm{a}, \mathrm{b}, \mathrm{c}, \mathrm{d}}$ & $141.9 \pm 20.4^{\mathrm{b}, \mathrm{c}, \mathrm{d}}$ & $151.6 \pm 22.9^{\mathrm{c}, \mathrm{d}}$ \\
\hline \multirow{3}{*}{ DPPH-IC ${ }_{50}(\mathrm{mg} / \mathrm{mL})$} & 0 & $24.65 \pm 5.23^{\mathrm{a}, \mathrm{b}, \mathrm{d}}$ & $22.60 \pm 4.55^{\mathrm{a}, \mathrm{b}, \mathrm{d}}$ & $19.28 \pm 4.04^{\mathrm{a}, \mathrm{b}, \mathrm{c}, \mathrm{d}}$ \\
\hline & 12 months & $17.02 \pm 2.75^{\mathrm{b}, \mathrm{c}, \mathrm{d}}$ & $15.64 \pm 2.12^{\mathrm{b}, \mathrm{c}}$ & $14.74 \pm 1.74^{\mathrm{b}, \mathrm{c}}$ \\
\hline & 24 months & $14.00 \pm 2.20^{\mathrm{b}, \mathrm{c}}$ & $13.50 \pm 2.04^{\mathrm{b}, \mathrm{c}}$ & $12.78 \pm 1.71^{\mathrm{b}, \mathrm{c}}$ \\
\hline \multirow{3}{*}{ FRAP value $(\mu \mathrm{M}$ Fe(II)) } & 0 & $149.6 \pm 40.4^{\mathrm{a}}$ & $164.0 \pm 41.8^{\mathrm{a}, \mathrm{b}}$ & $194.7 \pm 51.2^{\mathrm{a}, \mathrm{b}}$ \\
\hline & 12 months & $219.2 \pm 51.7^{\mathrm{a}, \mathrm{b}}$ & $237.1 \pm 51.0^{\mathrm{a}, \mathrm{b}}$ & $255.0 \pm 60.0^{\mathrm{a}, \mathrm{b}}$ \\
\hline & 24 months & $237.2 \pm 56.8^{\mathrm{a}, \mathrm{b}}$ & $249.6 \pm 53.8^{\mathrm{a}, \mathrm{b}}$ & $267.0 \pm 60.8^{\mathrm{b}}$ \\
\hline \multirow{3}{*}{$\begin{array}{l}\text { Fluorescence intensity at 280/350 nm } \\
\text { (a.u.) }\end{array}$} & 0 & $45.00 \pm 6.94^{\mathrm{a}}$ & $41.96 \pm 6.39^{\mathrm{a}}$ & $37.04 \pm 4.36^{\mathrm{a}}$ \\
\hline & 12 months & $24.83 \pm 2.65^{\mathrm{b}, \mathrm{c}, \mathrm{d}}$ & $22.98 \pm 2.57^{\mathrm{b}, \mathrm{c}, \mathrm{d}, \mathrm{e}}$ & $18.22 \pm 2.44^{\mathrm{b}, \mathrm{c}, \mathrm{d}, \mathrm{e}, \mathrm{f}}$ \\
\hline & 24 months & $17.66 \pm 1.75^{\mathrm{b}, \mathrm{c}, \mathrm{d}, \mathrm{e}, \mathrm{f}}$ & $15.48 \pm 2.04^{\mathrm{c}, \mathrm{d}, \mathrm{e}, \mathrm{f}}$ & $12.72 \pm 1.96^{\mathrm{c}, \mathrm{d}, \mathrm{e}, \mathrm{f}}$ \\
\hline \multirow{3}{*}{$\begin{array}{l}\text { Fluorescence intensity at } 360 / 460 \mathrm{~nm} \\
\text { (a.u.) }\end{array}$} & 0 & $152.90 \pm 14.56^{\mathrm{a}, \mathrm{d}}$ & $149.14 \pm 17.43^{\mathrm{a}, \mathrm{b}, \mathrm{d}}$ & $149.04 \pm 15.88^{\mathrm{a}, \mathrm{b}, \mathrm{d}}$ \\
\hline & 12 months & $127.40 \pm 13.88^{\mathrm{b}, \mathrm{c}, \mathrm{d}, \mathrm{e}, \mathrm{g}}$ & $123.00 \pm 9.08^{\mathrm{b}, \mathrm{c}, \mathrm{e}, \mathrm{f}}$ & $118.92 \pm 10.03^{\mathrm{b}, \mathrm{c}, \mathrm{e}, \mathrm{f}, \mathrm{g}}$ \\
\hline & 24 months & $106.48 \pm 8.12^{\mathrm{b}, \mathrm{c}, \mathrm{e}, \mathrm{f}, \mathrm{g}}$ & $101.38 \pm 8.46^{\mathrm{c}, \mathrm{e}, \mathrm{f}, \mathrm{g}}$ & $94.71 \pm 6.69^{\mathrm{c}, \mathrm{f}, \mathrm{g}}$ \\
\hline
\end{tabular}

Legend: GOX-glucose oxidase, AP-acid phosphatase, HMF-hydroxymethylfurfural, DPPH-IC 50 -honey concentration that causes a decrease of the initial DPPH radical concentration by $50 \%$. Values represented with same letters are not statistically different according to Tukey HSD test (p>0.05)

Having in mind that majority of enzymes are sensitive to elevated temperatures, causing enzyme denaturation, the obtained results are not surprising. The dynamics of change of selected physicochemical parameters was the same for all five analyzed samples. Statistically significant difference between unprocessed and processed samples, according to the Tukey HSD test, was determined for diastase, invertase and GOX activity while heating had no effect on acid phosphatase activity (table 2). Decrease of enzyme activity was more intense after heating at higher temperature, even $92 \%$ for invertase and $84 \%$ for GOX activity compared to unprocessed samples (table 2, figure 2). Obtained results confirm already reported information that invertase and GOX are more sensitive to heating than diastase (Karabournioti and Zeralaki, 2001; Dimiṇš et al., 2006). The intensity of changes depends greatly on honey botanical origin and therefore it is very difficult to compare the results for different honey types. The data about sage honey are very scarce while the data about the effect of processing and storage on sage honey characteristics are not available. Karabournioti and Zeralaki (2001) evaluated the impact of processing on thyme honey and they showed that invertase activity decreased from $70.64 \mathrm{U} / \mathrm{kg}$ (unprocessed honey) to $53.56 \mathrm{U} / \mathrm{kg}$ (after heating at $45^{\circ} \mathrm{C}$ ) and $6.35 \mathrm{U} / \mathrm{Kg}$ (after heating at $65^{\circ} \mathrm{C}$ ). The intensity of change is similar to those obtained in this study ( $28 \%$ after P1, and $92 \%$ after P2). Dimin̄s et al. (2006) showed that invertase activity of heather honey decreased to $50 \%$ of initial value after 2 years of storage that corresponds to the results in this study. 


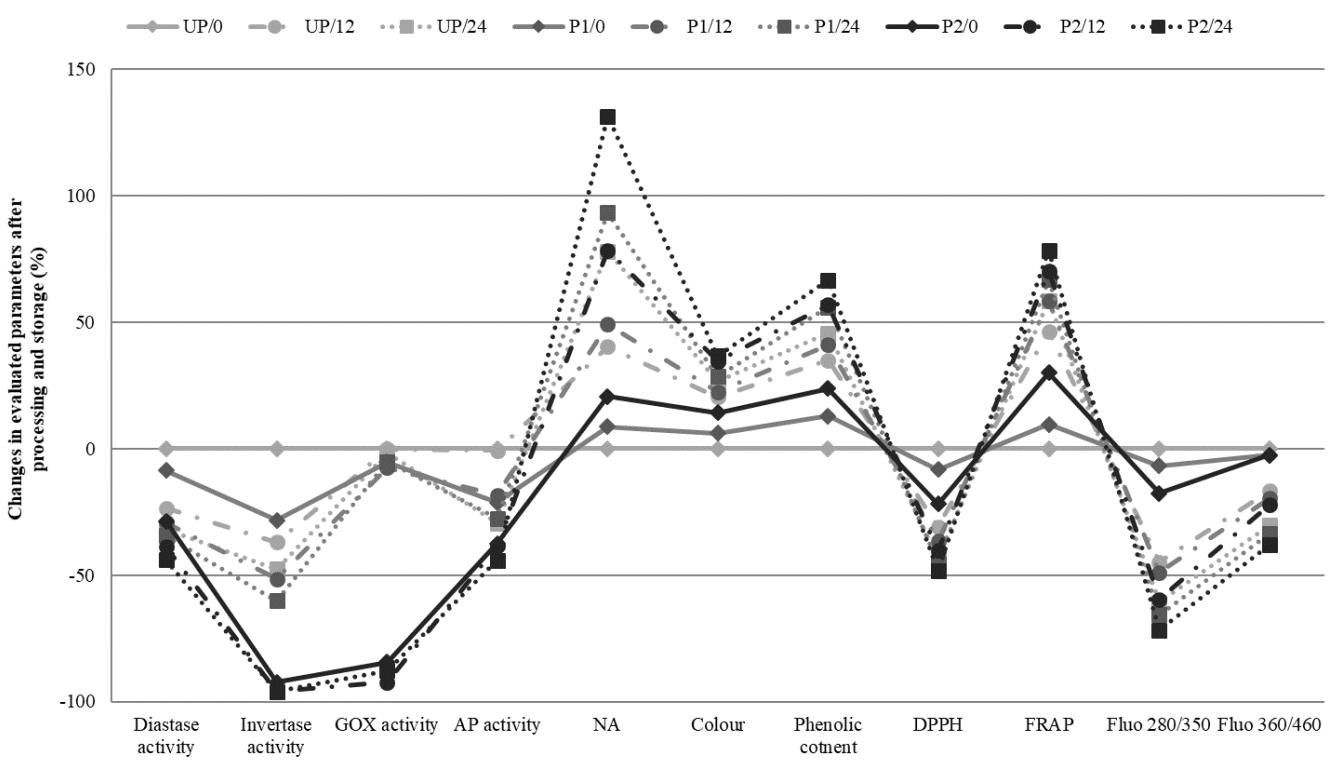

Figure 2 Intensity of changes (\%) of selected physicochemical parameters after processing and storage (UP-unprocessed, $\mathrm{P} 1-45^{\circ} \mathrm{C} / 48 \mathrm{~h}, \mathrm{P} 2-65^{\circ} \mathrm{C} / 6 \mathrm{~h} ; 0,12$ and 24 represent months of storage)

Storage caused further decrease of enzyme activity while preheating had no effect on decrease dynamics (table 2). The effect of processing and storage on HMF content are well described in the literature, but is it emphasized that dynamic of HMF formation significantly depend on botanical origin and chemica composition, primarily $\mathrm{pH}$ value of honey. Heating at lower temperature $\left(45^{\circ} \mathrm{C} / 48\right.$ h) had no effect on HMF content of sage honey, while higher temperature caused HMF increase by 1.5 times compared to unprocessed samples (table 2, figure 1). Nevertheless, all measured HMF values after processing/heating were lower than $10 \mathrm{mg} / \mathrm{kg}$, which indicates that processing conditions are suitable and HMF conten was within the limits for adequately processed honey. Limiting values for HMF as well as diastase activity are prescribed in national and international regulation (Codex Alimentarius Commission, 2001; Council of the European Union, 2002; Ministry of Agriculture, 2015). After two years of storage, average HMF content of preheated samples was higher than maximum value of $40 \mathrm{mg} / \mathrm{kg}$ $(43.7 \pm 8.1 \mathrm{mg} / \mathrm{kg}$ after $\mathrm{P} 1$ and $55.7 \pm 11.5 \mathrm{mg} / \mathrm{kg}$ after P2). This indicates the combined effect of processing/heating and storage on HMF formation. Therefore, it is recommended to store and consume sage honey in a period of less than two years

\section{Effect of processing and storage on colour}

Color of honey is one of the most important parameter for consumers' preference. Sage honey color ( $49 \pm 6 \mathrm{~mm}$ Pfund) is classified into extra light amber honey according to the USDA classification (United States Department of Agriculture, 1985). Processing and storage caused the darkening of sage honey, and average color values after two years of storage were $62 \pm 1,63 \pm 2$ and $67 \pm 3 \mathrm{~mm}$ Pfund (table 2 ), for unprocessed, and processed (P1 and P2) samples, respectively. According to the USDA classification, the color of analyzed samples after two years' storage changed into light amber (U.S. Department of Agriculture, 1985). Darkening of honey is attributed to the Maillard reaction products (MRPs) formation, fructose caramelization and phenolic components reactions (Pereyra Gonzales et al. 1999; Turkmen et al., 2006; Brudzynski and Miotto; 2011a). Increase of color was noted in both processed and unprocessed samples (table 2, figure 2) which indicated spontaneous formation of MRPs even in unprocessed samples during storage at room temperatures. Although color grading is standard method for honey color determination, spectrophotometric color determination (net absorbance) was proved to be better for monitoring of honey color change dynamics. Namely, melanoidins that are formed in final stage of Maillard reactions have characteristic absorption maximum between 420 and $450 \mathrm{~nm}$ (Brudzynski and Kim, 2011) Since, spectrophotometric color determination (net absorbance) is based on the absorbance measurement at 450 and $720 \mathrm{~nm}$, the increase of absorbance at $450 \mathrm{~nm}$ indicates the formation of melanoidins during processing and storage of honey.

Effect of processing and storage on phenolic content and antioxidant capacity

Antioxidant capacity of honey depends primary on its botanical origin and mostly is correlated to phenolic content and color. It is known that darker honey types have higher phenolic content and antioxidant capacity than lighter types (Bertoncelj et al., 2007; Flanjak et al, 2016a). Phenolic content and antioxidan capacity of various honey types is well documented in the literature, but the effect of processing and storage conditions on antioxidant capacity are limited and the results are quite different (Wang et al., 2004; Turkmen et al., 2006.; Brudzynski and Miotto, 2011a; Karabagias et al., 2018; Monggudal et al., 2018) Differences in obtained results can be attributed to the differences in processing (temperature-time) and storage conditions (temperature, presence of light) and sensitivity and precision of used methods. Processing increased phenolic content (on average $13 \%$ after P1 and $24 \%$ after P2) of sage honey (Figure 2). Increase of antioxidant capacity was greater for FRAP assay than DPPH assay, and the intensity of increase was dependent of preheating. The highest increase of FRAP value was observed in unprocessed samples (average $59 \%$ ) followed by P1 processed samples (average $52 \%$ ) and P2 processed samples (average $37 \%$ ). Increase of antioxidant/antiradical capacity determined by DPPH assay was observed after one year of storage while further storage had no impact on DPPH values (table 2). The observed differences in antioxidant activity between these two assays, might be explained by differences in assays mechanisms and components that react with reagents. Nevertheless, the observed increase of antioxidant capacity during processing and storage of sage honey can be partially attributed to the MRPs formation because it is known that some of them posses antioxidant activity (Brudzynski and Miotto, 2011a). Besides, MRPs might be also partially responsible for sage honey darkening during processing and storage. Strong relationship between formation of MRPs and increase of antioxidant capacity and color of honey was reported by Turkmen et al. (2006) and Brudzynski and Miotto (2011a,b)

\section{Effect of processing and storage on fluorescence intensity}

As reported in our previous study (Strelec et al., 2018) sage honey is characterized with two well defined fluorescence peaks, first dominant peak centered at 360/460 $\mathrm{nm}$, and second peak of lower intensity at $280 / 350 \mathrm{~nm}$. Fluorescence peak detected at $280 / 350 \mathrm{~nm}$ could be attributed to the fluorescence of aromatic amino acids Tyr Phe and Trp and/or proteins, as well to some phenolic acids (Strelec et al., 2012; Strelec et al., 2018), while those at $360 / 460 \mathrm{~nm}$ to the fluorescence of flavonoids (de Rijke et al., 2002; Strelec et al., 2018). Heating had no significant effect on fluorescence intensity at both excitation/emission wavelengths (table 2). However, during the storage there was a slight decrease in honey fluorescence. This could be attributed to the increased level of melanoidins, whose higher level in honeys during storage was observed as increase of honey color (table 2). Since honey melanoidins are multi-component polymers consisting of protein-polyphenololigosaccharide complexes (Brudzynski and Miotto, 2011a,b), where additiona interactions with honey flavonoids might not be neglected, multicomponent crosslinking of proteins, amino acids, sugars, polyphenols and flavonoids during honey storage probably caused decrease of fluorescence intensity. Namely, it is well known that interactions between flavonoids and proteins in solution might led to the shift and/or decrease of fluorescence intensity (Liu et al., 2010; Fu et al., 2012)

\section{CONCLUSION}

Processing and storage conditions used in this study were selected to simulate the real-life conditions that are mostly performed by the beekeepers and traders and afterwards to evaluate its effect on sage honey quality. The synergistic effect of processing and storage on honey quality was observed. Although the processing and storage increase phenolic content and antioxidant capacity, which is from nutritional aspect a desirable phenomenon, the general quality was considerably 
degraded to such a degree that after two years of storage at room temperature, preheated samples were not in compliance to regulations. Therefore, "best before" date for sage honey in which the compliance to the regulations is fulfilled and degradation of nutritive components are minimal is less than two years and it is advisable to processed it at low temperature as possible to achieve the processing effect.

Acknowledgments: The authors wish to thank Prof Dragan Bubalo (University of Zagreb, Faculty of Agriculture, Croatia) for the help with pollen analysis.

Conflict of Interest Statement: Authors declare no conflict of interest.

\section{REFERENCES}

AOAC International (2002). Official methods of analysis: Sugars and Sugar Products/Honey. pp. 22-33, Gaithersburg, Maryland.

Babacan, S., Pivarnik, L. F., \& Rand, A. G. (2002). Honey amylase activity and food starch degradation. Journal of Food Science: Food Chemistry and Toxicology, 67(5), 1625-1630. $\quad$ https://doi.org/10.1111/j.13652621.2002.tb08695.x

Benzie, I. F. F., \& Strain, J. J. (1996). The ferric reducing ability of plasma (FRAP) as a measure of "Antioxidant power": The FRAP assay. Analytical Biochemistry, 239, 70-76. https://doi.org/10.1006/abio.1996.0292

Beretta, G., Granata, P., Ferrero, M., Orioli, M., \& Facino, R. M. (2005) Standardization of antioxidant properties of honey by a combination of spectrophotometric/fluorimetric assays and chemometrics. Analytica Chimica Acta, 533, 185-191. https://doi.org/10.1016/j.aca.2004.11.010

Bergmeyer, H. U., Gawehn, K., \& Grassl, M. (1974). Enzymes as biochemical reagents. In Methods of enzymatic analysis, New York, USA

Bertoncelj, J., Doberšek, U., Jamnik, M. \& Golob, T. (2007). Evaluation of the phenolic content, antioxidant activity and colour of Slovenian honey. Food Chemistry, 105(2), 822-828. https://doi.org/10.1016/j.foodchem.2007.01.060

Brand-Williams, W., Cuvelier, M. E., \& Berset, C. (1995). Use of a free radical method to evaluate antioxidant activity. Lebensmittel-Wissenschaft und Technologie, 28, 25-30. https://doi.org/10.1016/S0023-6438(95)80008-5

Brudzynski, K., \& Kim, L. (2011). Storage-induced chemical changes in active components of honey de-regulate its antibacterial activity. Food Chemistry, 126, 1155-1163. https://doi.org/10.1016/j.foodchem.2010.11.151

Brudzynski, K., \& Miotto, D. (2011a). The recognition of high molecular weight melanoidins as the main components responsable for radical-scavenging capacity of unheated and heat-treated Canadian honeys. Food Chemistry, 125, 570-575 https://doi.org/10.1016/j.foodchem.2010.09.049

Brudzynski, K., \& Miotto, D. (2011b). The relationship between the content of Maillard reaction-like products and bioactivity of Canadian honeys. Food Chemistry, 124, 869-874. https://doi.org/10.1016/j.foodchem.2010.07.009

Codex Alimentarius Commission (2001). Revised Codex Standard for honey. Alinorm, 19-26.

Council of the European Union (2002). Council Directive 2001/110/EC of Dec 20, 2001, relating to honey. Official Journal of European Community, L10, 47-52. Čačić Kenjerić, F., Mannino, S., Bennedetti, S., Primorac, Lj., \& Čačić Kenjerić, D. (2009). Honey botanical origin determination by electronic nose. Journal of Apicultural Research and Bee World, 48(2), 99-103. https://doi.org/10.3896/IBRA.1.48.2.03

de Rijke, E., Joshi, H.C., Sanderse, H.R., Ariese, F., Brinkman, U.A.T., Gooijer, C. (2002). Natively fluorescent isoflavones exhibiting anomalous Stokes' shifts Analytica Chimica Acta, 468, 3-11. https://doi.org/10.1016/S00032670(02)00630-X

Dimiňš, F., Kūka, P., Kūka, M., \& Čakste, I. (2006). The criteria of honey quality and its changes during storage and therman treatment. Proceedings of the Latvia University of Agriculture, 16(311), 73-78.

Escriche, I., Visquert, M., Juan-Borrás, M., \& Fito, P. (2009). Influence of simulated industrial thermal treatments on the volatile fractions of different varieties of honey. Food Chemistry, 112, 329-338. https://doi.org/10.1016/j.foodchem.2008.05.068

Escriche, I., Kadar, M., Juan-Borrás, M., \& Domenech, E. (2014). Suitability of antioxidant capacity, flavonoids and phenolic acids for floral authentication of honey. Impact of industrial thermal treatment. Food Chemistry, 142, 135-143. https://doi.org/10.1016/j.foodchem.2013.07.033

Fauzi, N. A., Farid, M. M., \& Silva, F. V. M. (2014). High-pressure processing of manuka honey: Improvement of antioxidant activity, preservation of colour and flow behaviour. Food and Bioprocess Technology, 7, 2299-2307. https://doi.org/10.1007/s11947-013-1204-7

Flanjak, I., Kenjerić, D., Bubalo, D., \& Primorac, Lj. (2016a). Characterisation of selected Croatian honey types based on the combination of antioxidant capacity, quality parameters, and chemometrics. European Food Research and Technology, 242, 467-475. https://doi.org/10.1007/s00217-015-2557-0

Flanjak, I., Strelec, I., Kenjerić, D. \& Primorac, Lj. (2016b). Croatian produced unifloral honeys characterised according to the protein and proline content and enzyme activities. Journal of Apicultural Science, 60(1), 39-48 https://doi.org/10.1515/jas-2016-0005

Fu, Z.D., Chen, X.Q., \& Jiao, F.P. (2012). Study of the interaction of galangin, kaempferol and quercetin with BSA. Latin American Applied Research, 42, 211 216

International Honey Commission (2009). Harmonised methods of the International Honey Commision. http://www.ihc-platform.net/ihcmethods2009.pdf

Karabournioti, S. \& Zervalaki, P. (2001). The effect of heating on honey HMF and invertase. Apiacta, 36(4), 177-181.

Karabagias, V.K., Karabagias, I.K:, \& Gatzias, I. (2017). The impact of different heating temperatures on physicochemical, color attributes, and antioxidant activity parameters of Greek honeys. Journal of Food Process Engineering, e12668. https://doi.org/10.1111/jfpe.12668

Kenjerić, D., Mandić, M. L., Primorac, Lj., \& Čačić, F. (2008). Flavonoid patter of sage (Salvia officinalis L.) unifloral honey. Food Chemistry, 110, 187-192. https://doi.org/10.1016/j.foodchem.2008.01.031

Kenjerić, D., Primorac, Lj., Mandić, M. L., Bubalo, D., Perl Pirički, A., \& Flanjak, I. (2006). Dalmatian sage (Salvia officinalis L.) honey characterisation. Deutsche Lebensmittel-Rundschau, 102(10), 479-484.

Kowalski, S. (2013). Changes of antioxidant activity and formation of 5 hydroxymethylfurfural in honey during thermal and microwave processing. Food Chemistry, 141, 1378-1382. https://doi.org/10.1016/j.foodchem.2013.04.025

Liu, E.-H., Qi, L-W., \& Li, P. (2010). Structural relationship and binding mechanisms of five flavonoids with bovine serum albumin. Molecules, 15, 9092 9103. https://doi.org/10.3390/molecules 15129092

Louveaux, J., Maurizio, A., \& Vorwohl, G. (1978). Methods of melissopalynology. Bee World, 59, 139-157. https://doi.org/10.1080/0005772X.1978.11097714

Merve Turkut, G., Degirmenci, A., Yildiz, O., Can, Z, Cavrar, S., Yaylaci Karahaili, F., \& Kolayli, S. (2018). Investigation of 5-hydroxymethylfurfural formation kinetic and antioxidant activity in heat treated honey from different floral sources. Journal of Food Measurement and Characterization, 12, 2358-365. https://doi.org/10.1007/s11694-018-9852-y

Ministry of Agriculture (2015). Regulation on the quality of honey. Official Gazette 30, 3-5.

Ministry of Agriculture, Fisheries and Rural Development (2009). Regulation on the quality of unifloral honey. Official Gazette, 122, 15-16.

Monggudal, M. B., Radzi, M. N. F. M., Ismail, M. M., \& Ismail, W. I. W. (2018) Effect of six month storage on physicochemical analysis and antioxidant activity of several types of honey. IOP Conference Series: Materials Science and Engineering, 440, 012047. https://doi.org/10.1088/1757-899x/440/1/012047

Önür, İ., Misra, N. N., Barba, F. J., Putnik, P., Lorenzo, J. M., Gökmen, V., \& Alpas, H. (2018). Effects of ultrasound and high pressure on physicochemical properties and HMF formation in Turkish honey types. Journal of Food Engineering, 219, 129-136. https://doi.org/10.1016/j.jfoodeng.2017.09.01

Pereyra Gonzales, A., Burin, L, \& del Pilar Buera, M. (1999). Color changes during storage of honeys in relation to their composition and initial color. Food Research International, 32, 185-191. https://doi.org/10.1016/S0963-9969(99)00075-7

Piana, M.L., Persano Oddo, L., Bentabol, A., Bruneau, E., Bogdanov, S., Guyot Declerck, C. (2004). Sensory analysis applied to honey: state of the art. Apidologie, 35, S26-S37. https://doi.org/10.1051/apido:2004048

Primorac, Lj., Flanjak, I., Kenjerić, D., Bubalo, D., \& Topoljnjak, Z. (2011). Specific rotation and carbohydrate profile of Croatian unifloral honeys. Czech Journal of Food Sciences, 29, 515-519. https://doi.org/10.17221/164/2010-CJFS Radtke, J., \& Lichtenberg-Kraag, B. (2018). Long-term changes in naturally produced honey depending on processing and temperature. Journal of Apicultural Research, 57(5), 615-626. https://doi.org/10.1080/00218839.2018.1494893

Schepartz, A. I., \& Subers, M. H. (1964). The glucose oxidase of honey. I.Purification and some general properties of the enzyme. Biochimica et biophysica acta, 85, 228-237. https://doi.org/10.1016/0926-6569(64)90243-3

Strelec, I., Brodar, L., Flanjak, I., Cačić Kenjerić, F., Kovač, T., Cačić Kenjerić, D., \& Primorac, Lj. (2018). Characterization of Croatian honeys by right-angle fluorescence spectroscopy and chemometrics. Food Analytical Methods, 11(3), 824-838. https://doi.org/10.1007/s12161-017-1059-Z

Strelec, I., Kučko, L., Roknić, D., Mrša, V., \& Ugarčić-Hardi, Ž., 2012. Spectrofluorimetric, spectrophotometric and chemometric analysis of wheat grains infested by Sitophilus granarius. Journal of Stored Products Research, 50, 42-48 https://doi.org/10.1016/j.jspr.2012.04.004

Subramanian, R., Umesh Hebbar, H., \& Rastogi, N. K. (2007). Processing of honey: a review. International Journal of Food Properties, 10, 127-143. https://doi.org/10.1080/10942910600981708

Turhan, I., Tetik, N., Karhan, M., Gurel, F., \& Reyhan Tavukcuoglu, H. (2008). Quality of honeys influenced by thermal treatment. LWT-Food Science and Technology, 41(8), 1396-1399. https://doi.org/10.1016/j.lwt.2007.09.008

Turkmen, N., Sari, F., Poyrazoglu, E.S., \& Velioglu, Y.S. (2006). Effects of prolonged heating on antioxidant activity and colour of honey. Food Chemistry, 95(4), 653-657. https://doi.org/10.1016/j.foodchem.2005.02.004

United States Department of Agriculture (1985). United States Standards for Grades of Extracted Honey. http://www.ams.usda.gov/AMSv1.0/getfile?dDocName=STELDEV3011895 
Von der Ohe, K., \& von der Ohe, W. (2003). Celle's melissopylinological collection (2nd ed.). Celle, Germany.

Von der Ohe, W., Persano Oddo, L., Piana, M.L., Morlot, M., \& Martin, P. (2004) Harmonized methods of melissopalynology. Apidologie, 35, S18-S25. https://doi.org/10.1051/apido:2004050

Wang, X-H., Gheldof, N., \& Engeseth, N.J. (2004). Effect of processing and storage on antioxidant capacity of honey. Journal of Food Science:Food Chemistry and Toxicology, 69(2), 96-101. https://doi.org/10.1111/j.13652621.2004.tb15509.x

Wilczyńska, A. (2014). Effect of filtration on colour, antioxidant activity and total phenolics of honey. LWT-Food Science and Technology, 57, 767-774. https://doi.org/10.1016/j.lwt.2014.01.034 